\title{
DETERMINANTS AND OUTCOMES OF MOBILE APP USAGE INTENTION OF GEN Z: A CROSS CATEGORY ASSESSMENT
}

\section{Edin Güçlü SÖZER ${ }^{1}$}

\begin{abstract}
The objective of this study is to identify the determinants such as usefulness and ease of use as well as the behavioral outcomes of mobile app usage intention among Generation $\mathrm{Z}$ consumers. Three mobile app categories, entertainment, communication and networking, are included in the study. The results of the study confirmed that perceived ease of use plays an important role in determining the intention to use the app while perceived privacy, perceived security, perceived design and perceived compatibility are the factors which shape both perceived ease of use and usefulness depending on the mobile app category. Higher usage intention is found to be effective in generating willingness to pay in all mobile app categories. In contrast to the entertainment category, increasing usage intention is also found to lead increasing intention to engage into the WoM activity in communication and networking categories. Based on these findings, some practical implications are provided.
\end{abstract}

Keywords: Mobile App, Usage Intention, Willingness to Pay, Word of Mouth, Generation Z.

JEL Classification: M30, M37, M39

\section{Z KUŞAĞINDA MOBILL UYGULAMA KULLANIMI BELİRLEYICILERİ VE SONUÇLARI: KATEGORILER ARASI BİR İNCELEME}

\section{$\ddot{O} \mathbf{z}$}

Bu çalışmanın amacı $\mathrm{Z}$ kuşağı tüketicilerinin mobil uygulamaları kullanma niyetlerini etkileyen kullanışlılık ve kullanım kolaylığı gibi faktörlerin ve söz konusu kullanma niyetinin davranışsal sonuçlarının tespit edilmesidir. Araştırmaya eğlence, iletişim ve sosyal ağ kategorilerindeki mobil uygumalar dahil edilmiştir. Elde edilen bulgular sşığında, uygulamaya yönelik kullanım kolaylığı algısının uygulamayı kullanma niyetine etki ettiği sonucuna ulaşılmışırı. Mobil uygulamanın kategorisine bağlı olarak, mahremiyet algısı, güvenlik algısı, tasarım algısı ve uyumluluk algısının ise kullanım kolaylığı ve kullanışlılık algıları üzerinde etkili oldukları tespit edilmiştir. Tüm mobil uygulama kategorilerinde kullanım niyetinin güçlenmesinin ödeme yapma niyeti üzerinde pozitif bir etki yarattığı tespit edilmiştir. Diğer taraftan, yine güçlenen kullanma niyetinin, iletişim ve sosyal ağ kategorilerinde bilgiyi yayma eğiliminde artışa neden olduğu ancak bu etkinin eğlence kategorisinde geçerli olmadığı tespit edilmiştir. Araştırmanın bulguları kapsamında uygulamaya yönelik öneriler sunulmuş̧tur.

Anahtar Kelimeler: Mobil Uygulama, Kullanım Niyeti, Ödeme Niyeti, Bilgi Yayma, Z Kuşağı.

JEL Sinıflaması: M30, M37, M39

\section{Introduction}

The rapid adoption of internet-enabled mobile devices as well as the increasing internet penetration rates, lead to the emergence of new platforms which provide real time interaction between companies and consumers. According to the report provided by Statista (2019), 63\% of consumers who use a mobile phone and subscribed to a GSM service are expected to have also an internet access through their mobile phone in 2019.

\footnotetext{
${ }^{1}$ Asst. Prof., Istanbul Okan University, Faculty of Business and Administrative Sciences, Istanbul, Turkey, edin.sozer@ okan.edu.tr, ORCID: 0000-0003-4984-4629.
} 
Wide adoption of smart mobile phones with internet access as the tools of communication as well as transaction, led to a shift in the focus of marketers on these promising platforms.

The emergence of this new interactive platform and the shift in the focus of marketers, made the mobile marketing activities as one of the major tools to engage with customers and consequently provided companies the opportunity to build, maintain and enhance their relationship with target consumers (Varnalı \& Toker, 2010). Moreover, starting with the introduction of iTunes application store in 2007 and following the fast adoption by marketers as one of the mobile marketing tools (Benitez \& Martinez, 2015), mobile apps supported the effectiveness of mobile marketing activities since they provide a unique platform for the companies to interact with their target consumers. The number of mobile apps in the market, which are regarded as the brands in hand (Sultan \& Rohm, 2005), reached at 4.1 million in Android and Apple app stores as of the third quarter of 2018. There is a considerable consumer demand to use these apps which resulted into the global consumer spending of 89 billion $\$$. The total spending is expected to tap 189 billion \$ in 2020 (Statista, 2019). As the apps are personal, portable and flexible in terms of time and space, when consumers consider an app as a relevant one, they download and start to use it (Vishvanathan et al., 2017). Thus, these apps can be considered as one of the important tools to be used for engaging with customers and a way of complementing and extending the physical and virtual channels of brands (Stocchi et al., 2019). Although the wide range adoption of apps and growing consumer spending are promising developments, due to the app-clutter and noise in this market, app developers and brands face the difficulty of convincing consumers to download, use and recommend their apps to other potential users. Consumers use around one third of the apps they already downloaded and even they use less of the branded apps (Siti et al. 2016). This situation requires marketers to consider the ways to successfully place their apps into the consideration list of consumers and convincing them to download and use their apps. In order to succeed this, they need to identify the factors which have an influence on the app adoption of consumers and the outcomes of a possible satisfaction with the app usage.

One way of segmenting consumers is to group them by their common personal characteristics which are formed as a result of the interaction between their year of birth and the major social, economic, political and cultural trends of that period (Altuntuğ, 2012). This categorization leads us to use the terminology "Generations" for those consumers which differ from each other in terms of values, attitudes and beliefs as the result of these factors (Reisenwitz \& Iyer, 2007). A general classification, which is widely accepted, identifies five types of generations, namely Silent, Baby Boomers, X, Y and Z. Although there are different types of identification for the generational cohorts, many research studies define these cohorts and their year of birth as Silent (Before 1960), Baby Boomers (1946-1960), Generation X (1961-1979), Generation Y (19801995) and finally Generation Z who born after 1995 (Gurau, 2012; Barford \& Hester, 2011; Queitzsch, 2015; McCrindle \& Wolfinger, 2010). Compared to previous generations, as a more educated and technology literate one, Generation X witnessed both economic and societal uncertainties in their time span which made them skeptical and pragmatic type of persons (Jackson et al. 2011; Lyons et al. 2007). On the other hand, members of Generation Y, who can be considered the members of the first high tech generation of the world (Norum, 2003), are motivated with consumption and they can be regarded as sophisticated shoppers (Eastman \& Liu, 2012). 
This socially motivated generation has a very high level of spending power, but at the same time they are economically conscious, and they are immune to environmental factors in retailing context (Hewlett et al, 2009; Martin \& Turley, 2004).

On the other hand, there is a need for closer look at Generation $\mathrm{Z}$ in terms of their potential, capabilities and characteristics. First, this generation is expected to constitute $32 \%$ of global population by 2019 and $40 \%$ of all consumers by 2020 (Chan, 2019). Thus, they will be a potential and target consumer segment for the brands soon. On the other hand, Generation Z, the digital natives, are also the most technology enabled and skillful generation compared to previous generations. In this wired and digitally connected world, they will be the users of many platforms and their adoption rates will be the highest among other generations. Third, as consumers, they have differentiating characteristics compared to previous generations in a way that they are more demanding, have higher expectations from the brands, they look for experiences and show no loyalty (Schlossberg, 2016; Lee, 2009). Another important characteristic of this generation is that, as they are more connected, network effects, word of mouth and close circle recommendations have an important influence on their decisions as consumers and all these characteristics make them a unique generation with their choices and preferences (Siti et al, 2016). The adoption rate of mobile apps among different generations is the highest for Generation Z. According to the report provided by e-Marketer (2018), Generation $Z$ leads the way as having the highest rate of mobile social app usage in US over other generations including the Generation Y (Millennials.) Thus, they constitute a potential segment for the marketers who will offer mobile apps as the main channel of communication and transaction for their brands. Due to the increasing number of apps in the market, it becomes an essential issue to identify the factors which motivate Generation $\mathrm{Z}$ to use the apps and the consequences of generating such usage intention for this segment.

Although there are studies in the existing literature which measure the determinants or outcomes of mobile app adoption in several contexts, to the best of our knowledge, there is a lack of studies which measure both the adoption factors as well as outcomes of mobile app usage intention in Generation $\mathrm{Z}$ both in a holistic model and in a single study employing multiple app categories. In this perspective, this study has two objectives: First, it is aimed to identify the factors which are influential on the adoption of mobile apps by Generation Z. Secondly, the study also aims to identify the outcomes of having an intention to use an attractive mobile app. The study contributes to the existing literature by employing the conceptual model proposed and tested by Stocchi et al. (2019) and testing it in the generational context within multiple app categories. Based on the objectives and conceptual framework of the study, the following research questions are addressed:

- Does the perceived usefulness influence the usage intention of mobile app?

- Does the perceived ease of use influence the usage intention of mobile app?

- Which characteristics of mobile app influence perceived usefulness of the app?

- Which characteristics of mobile app influence perceived ease of use of the app?

- Does the usage intention of app influence the intention to engage into WoM?

- Does the usage intention of app influence the willingness to pay for the services? 


\section{Determinants of Usage Intentions for Mobile Apps}

The careful review of the literature which deals with the dynamics and sub-applications of mobile marketing and digital technologies shows that the dominant theoretical framework utilized to explain the adoption factors as well as the outcomes is the Technology Acceptance Model (TAM) developed by Davis (1989). Based on the Theory of Reasoned Action (TRA), TAM explains the adoption of an information technology tool as the product of attitude towards using information technology and its perceived usefulness for the consumer. The model proposes perceived usefulness and ease of use as the determinants of the attitude towards the information technology. TAM can be considered as one of the most referenced and dominant theoretical frameworks used to explain the adoption of technology in different contexts (Venkatesh et al. 2007).

Many studies in the literature focused on the validation of the TAM model and measured the effects of TAM factors on technology adoption in various contexts. In their study, Rohm et al. (2012) investigated the factors which influence the acceptance of mobile marketing by consumers in three markets, namely United States, Europe and China. Specifically, they targeted to measure the effects of perceived usefulness and individual characteristics, the original constructs of TAM. Authors reported the significant influence of perceived usefulness, personal attachment and consumer innovativeness as the determinants of mobile marketing acceptance in all three markets. Another study conducted by Wu and Wang (2005) employed also some constructs from the TAM to identify the factors which influence the mobile commerce adoption. The authors integrated the TAM model with the diffusion of innovation theory, risk perceptions as well as perceived cost and reported the significant effect of several factors including perceived usefulness, perceived compatibility, perceived risk and perceived cost as the determinants of mobile commerce acceptance. Siamagka et al. (2015) investigated the adoption of social media in the B2B context by employing several TAM constructs. The authors reported that the adoption of social media by the organizations is influenced by the perceived usefulness and organizational innovativeness. Another study in the mobile services context investigated the determinants of the actual usage of such services by employing several TAM related constructs and reported that ease of use and service ubiquity influence the experiential value of such services and this leads to actual service usage (Tojib \& Tsarenko, 2012). There are also some studies which employed the TAM constructs in explaining the mobile app adoption of consumers. Yang (2013) investigated the factors influencing the adoption of mobile app decisions of college students in United States. Among other factors, the author reported perceived usefulness and ease of use as the determinants of attitudes and perceived usefulness as one of the determinants of mobile app usage. Similarly, Stocchi et al. (2019), employed TAM in their study and found that perceived usefulness and ease of use are the determinants of app usage. The employment of TAM for the explanation of the adoption dynamics related to mobile apps can be justified in a way that previous studies in the literature dealing with the adoption of technological products, services or applications already employed TAM and produced satisfactory results which makes it a valid, reliable and responsive theoretical framework (Stocchi et al. 2019; Porter \& Donthu, 2006).

In the light of previous studies and the effectiveness of TAM in explaining the adoption process in digital technologies, this study also employs the TAM as the ground of the theoretical framework. 
The conceptual model employed in this study is based on the model proposed and tested by Stocchi et al. (2019), which includes perceived usefulness and perceived ease of use as the determinants of mobile app usage intention.

\subsection{The Effects of Perceived Usefulness and Ease of Use on Mobile App Usage Intention}

When consumers believe that using a tool or system will enhance the performance or will provide an advantage to the user, this reflects its degree of usefulness. On the other hand, perceived ease of use is related with the ability to use the tool or system without any physical or cognitive effort (Davis, 1989). Several studies in the literature report the significant influence of both perceived usefulness and ease of use on the adoption and usage of mobile technologies. Shih (2004) combined TAM and information behavior model to explain the determinants of internet adoption process in Taiwan. The results of the study confirmed that, alongside other factors, perceived usefulness and ease of use were the two factors influencing the attitude of consumers towards the internet usage. Similarly, Natarajan et al. (2017) measured the effects of perceived usefulness and ease of use on satisfaction and intention to use mobile shopping applications. Authors confirmed that these two factors (perceived usefulness and ease of use) significantly influence the satisfaction and intention to use of mobile shopping applications. Hur et al. (2017) investigated the effects of perceived usefulness on app usage intention in the fashion industry and compared the effects of this factor for millennial and mature consumer groups. Authors reported significant effect of perceived usefulness on usage intentions in both consumer groups. There are also some studies which show contradictory results related to the effects of perceived usefulness and ease of use. Dai and Palvia (2009) measured the effect of perceived usefulness and ease of use on the intention to use mobile commerce in China and USA. The results of the study confirmed the significant influence of both factors on the intention to use mobile commerce in China. However, the results of USA consumers confirmed only the significant effect of perceived usefulness on the intention to use mobile commerce. Perceived ease of use was not found significantly influencing the intention to use mobile commerce. In another study, Koenig et al. (2015) investigated the effect of perceived usefulness and ease of use on the mobile payment app adoption and reported the significant influence of perceived usefulness on the intention to use. However, the authors reported no significant effect of ease of use on intention to use mobile payment app.

Existing studies in the literature report both conclusive and inconclusive results in terms of the effects on intention to use apps depending on the context. In this perspective, we believe that the influence of these factors should be investigated in younger generations as well among different app categories. Thus, in the light of the theoretical background and the findings in the literature, we propose the following hypotheses:

$\mathrm{H}_{1}$ : Higher levels of perceived usefulness will lead to higher levels of intention to use.

$\mathrm{H}_{2}$ : Higher levels of perceived ease of use will lead to higher levels of intention to use.

\subsection{Factors Influencing Perception of Usefulness, Ease of Use and Mobile App Usage Intention}

A group of characteristics are influential when consumers evaluate and consider adopting a new technological tool (Arts et al. 2011). As one of the technological tools, when we consider mobile apps, the characteristics of these apps are also expected to be the determinants of the consumer perceptions regarding the perceived usefulness and ease of use of these mobile apps. 
In line with the model proposed and tested by Stocchi et al. (2019) based on the TAM, this study employs perceived security, privacy, design, ubiquity and compatibility as the determinants of perceived usefulness and ease of use related to the mobile apps.

Security perceptions of consumers derive from the technical security strength of a technological tool and it involves the capability of this tool to prevent unauthorized access by third parties (Nikkhah et al. 2018). As the mobile apps are accessed through wireless networks in contrast to wired networks, the risk of vulnerability to third party attacks and interventions may be higher and consumers are expected to be more sensitive to security issues (Crabbe et al. 2009). On the other hand, a related but distinct concept is the perceived privacy. Generally, it can be defined as the perception generated as a result of the consumers' ability to control the personal information sharing while using the technological tool (Smith et al. 2011). Due to their close interaction, there are also studies in the literature which consolidate them into a single construct (Shin, 2010). Previous research focused on the security and privacy as the two factors which influence the adoption of technology both directly and indirectly through perceived usefulness and ease of use. Sathye (1999) investigated the effect of several factors on the adoption of internet banking in Australia and reported security concerns as one of the blocking factors. Similarly, Polasik and Wisniewski (2008) focused on the adoption factors of online banking in Poland. Authors reported a significant effect of security perception on the online account opening of consumers. However, Pikkarainen et al. (2004) focused also on the effect of perceived security and privacy on the adoption of online banking and reported no significant effects. Lallmahamood (2007) included perceived security and privacy as an external variable in the TAM model and measured both direct and indirect effects of these two factors on the online banking adoption. The author reported significant direct effects. Similarly, Stocchi et al. (2019) investigated the indirect effects of perceived security and privacy on the mobile app usage intention and reported significant positive effects of these two factors on the perceived usefulness and ease of use mobile apps which eventually influence intentions to use the apps. In the light of the TAM framework and the findings in the existing literature, the following hypotheses are proposed:

$\mathrm{H}_{3}$ : Positive privacy perceptions will lead to higher levels of perceived usefulness.

$\mathrm{H}_{4}$ : Positive privacy perceptions will lead to higher levels of perceived ease of use.

$\mathrm{H}_{5}$ : Positive security perceptions will lead to higher levels of perceived usefulness.

$\mathrm{H}_{6}$ : Positive security perceptions will lead to higher levels of perceived ease of use.

Another important factor which is expected to be influential on the perceived usefulness and ease of use is the design of the mobile app. The design of an app includes the visual identity, lay-out, presentation and the required functionality to meet the needs of consumers (DeLone \& McLean, 1992). Generating effective designs both in web sites as well as mobile apps are expected to generate positive outcomes in terms of consumer response (Kim, 2012). Previous studies in the literature reported significant effect of design on the effectiveness of web sites and mobile apps. Cho and Park (2001) focused on the determinants of customer satisfaction of web sites and reported the significant effect of website design. In another study, Lee \& Lin (2005) reported the significant effect of website design on both customer satisfaction and perceived quality. 
Similarly, Chiu and Yang (2016) measured the effect of web site design on the web site user experience and the perception of usefulness and reported significant effects on these two outcomes which ultimately affect the attitude formation and behavioral intentions. Krishnan and How (2016) investigated the effects of app design on consumer intention to download the app and reported significant effect of design elements. In another study, Stocchi et al. (2019) reported the significant effect of mobile app design characteristic on perceived usefulness and ease of use regarding the mobile app. The theoretical framework provided by TAM and the findings of the literature lead us to propose the flowing hypotheses:

$\mathrm{H}_{7}$ : Positive design perceptions will lead to higher levels of perceived usefulness.

$\mathrm{H}_{8}$ : Positive design perceptions will lead to higher levels of perceived ease of use.

Following its introduction (Watson et al. 2002), ubiquity has become a concept which is increasingly mentioned by many authors as one of the important factors affecting the adoption of wireless technologies including mobile apps. In a broad definition it refers to the ability of accessing the information without any restrictions (Looney et al. 2004). When wireless networks are considered, ubiquity can be regarded as one of the most important advantages provided to consumers (Sarker \& Wells, 2003). Similarly, in case of mobile apps, perceived ubiquity of consumers refers to the ability of mobile apps to provide the consumer the opportunity to reach at the services continuously without any time and space restrictions. In their study, Tojib and Tsarenko (2012) investigated the antecedents of advanced mobile service usage and reported the service ubiquity as one of the determinants of ease of use which leads to actual usage through experiential value. Kim and Garrison (2009) proposed the extension of TAM to Mobile Wireless Technology Acceptance Model (MWTAM) and investigate the effects of technological influence processes and cognitive influential processes on the behavioral intentions. Authors reported the significant effect of perceived ubiquity on behavioral intention of consumers. Roy and Moorthi (2017) investigated the effect of perceived ubiquity on m-commerce adoption and reported the significant effect. Similarly, Stocchi et al. (2019) reported the significant effect of perceived ubiquity on perceived usefulness and ease of use regarding the mobile app. In the light of the TAM framework and the findings in the existing literature, the following hypotheses are proposed:

$\mathrm{H}_{9}$ : Positive Perceived ubiquity will lead to higher levels of perceived usefulness.

$\mathrm{H}_{10}$ : Positive Perceived ubiquity will lead to higher levels of perceived ease of use.

Another important factor which is widely cited in the literature as the determinant of technological adoption is compatibility. In the most accepted definition, compatibility involves the positive perception of an innovation regarding the suitability and consistence with the values, beliefs, experiences and needs of users (Rogers, 1962). Compatibility is further conceptualized into two types as cognitive and operational, where cognitive compatibility, on one hand, is related with the opinions or feelings of consumers about the compatibility performance of the innovation and operational compatibility, on the other hand, is related with need-based compatibility (Tornatzky \& Klein, 1982). In their study, Kim et al. (2009), measured the influence of cognitive compatibility factors on the adoption of mobile entertainment services and reported the significant effect of normative factors on the adoption of such services. Kang et al. (2015) investigated the influence of compatibility perception regarding the retail apps with mobile location-based services on consumer involvement and usage intention. 
Authors reported the significant effect of perceived compatibility on affective involvement which eventually leads to intention to download the apps. In another study, the compatibility was reported as one of the determinants of trial of service technologies (Meuter et al., 2005a). According to Kang et al. (2015), the operational compatibility is closely related to the consumers' perceptions of functionality and usefulness. This is confirmed by the study of Stocchi et al. (2019) where they reported the significant effect of compatibility on perceived usefulness and ease of use in the context of mobile apps. The theoretical framework provided by TAM and the findings of the literature lead us to propose the flowing hypotheses:

$\mathrm{H}_{11}$ : Higher Perceived compatibility will lead to higher levels of perceived usefulness.

$\mathrm{H}_{12}$ : Higher Perceived compatibility will lead to higher levels of perceived ease of use.

\section{Outcomes of Mobile App Usage Intentions}

\subsection{The Effect of Usage Intentions on Willingness to Pay for the App}

As one of the new forms of interactive media and distinct from others such as web sites and mobile advertising, mobile apps are useful tools for marketers which generate high levels of engagement with consumers (Bellman et al. 2011). Consumers, who show some propensity to use the mobile app, generally download the app to test it and then depending on their experience they decide to keep it or not. In case of paid apps with baseline and upgraded versions, after a successful testing period, they may consider upgrading to ad-free version or purchase additional features. That is, intention to use the mobile app also relates to the intention to pay for the app. Intention to pay, or purchase intention, can be regarded as a plan of consumer to make a purchase and it can be realized when the motivation and features are matched (Spears \& Singh, 2004; Belch \& Belch, 2003). The strong connection between the behavioral intention and actual behavior or action is derived from the Theory of Reasoned Action (TRA) and its extension, Theory of Planned Behavior (TPB) (Werner, 2004). According to TRA, a strong intention leads to the higher likelihood of the realization of such action. TPB, on the other hand, assumes that the lack of perceived behavioral control, leads to the blocking of such action. In case a person does not perceive as having a behavioral control, such as how easy or difficult of realizing such action, the intention does not transform to actual behavior. There are numerous meta-analysis studies of TRA and TPB which focus on the association between the intention and actual behavior. In their study, Hausenblas et al. (1997) reported a moderate level of correlation between intention and actual purchase. There are also additional meta-analysis studies which report significant correlation between intention and actual behavior (Albarracin et al. 2011; Sheeran et al. 1999). These results lead us to conclude that behavioral intention may result in actual behavior in the absence of some moderating and intervention factors. In the light of the theoretical framework and findings in the existing literature, the following hypothesis is proposed:

$\mathrm{H}_{13}$ : Higher usage intention will lead to higher willingness to pay for the upgraded app.

\section{Communication \\ 3.2. The Effect of Usage Intentions on Engaging into WoM}

The behavior of consumers is mediated by the interactional processes such as exchange of information (Darden \& Reynolds, 1971). 
When this interaction generally takes the form of non-commercial conversations about the products or services of a company, it is referred to as Word of Mouth (WoM). WoM communication is an important tool for marketers since it has important cognitive, affective and conative effects on consumer behavior (Brown \& Reingen, 1987). Several studies in literature confirmed the significant effect of WoM communication on the adoption of new products, on consumer attitudes, perceptions and on their purchase decisions (Arndt, 1967; Bone, 1995; Bansal \& Voyer, 2000). Consumers also benefit from engaging into WoM communication since they mitigate the risk of incorrect purchase decisions. The motivation of consumers for engaging in such interactions with other consumers through WoM can be explained on the grounds of Social Exchange Theory (Thibaut \& Kelley, 1959). The theory suggests that parties engage in social exchange transactions, such as information sharing, to maximize the benefits and minimize the risks. Thus, consumers are motivated to establish a shared source of information network through WoM communication which is expected to help them to reduce the uncertainties related to product or service purchases. In this perspective, consumers are expected to share the information about the mobile app when they intend to use the particular app. Previous studies in the mobile app context also confirm the significant effect of usage intentions on engaging in WoM communication and sharing the information. In their study, Xu et al. (2015), investigated the antecedents of Customer Value, Satisfaction and Loyalty Framework (VSL) on mobile app users. The authors reported that along with other factors, app continuance intention of usage is a strong determinant of app recommendation. Similarly, Stocchi et al. (2019) also measured the effect of mobile app usage intention on WoM engagement and reported a significant and positive effect. The theoretical framework as well as the findings of the previous studies leads us to propose the following hypothesis:

$\mathrm{H}_{14}$ : Higher usage intention will lead to higher level of WoM engagement intention.

In line with the hypothesis proposed, the following conceptual model presented in Figure 1 was developed.

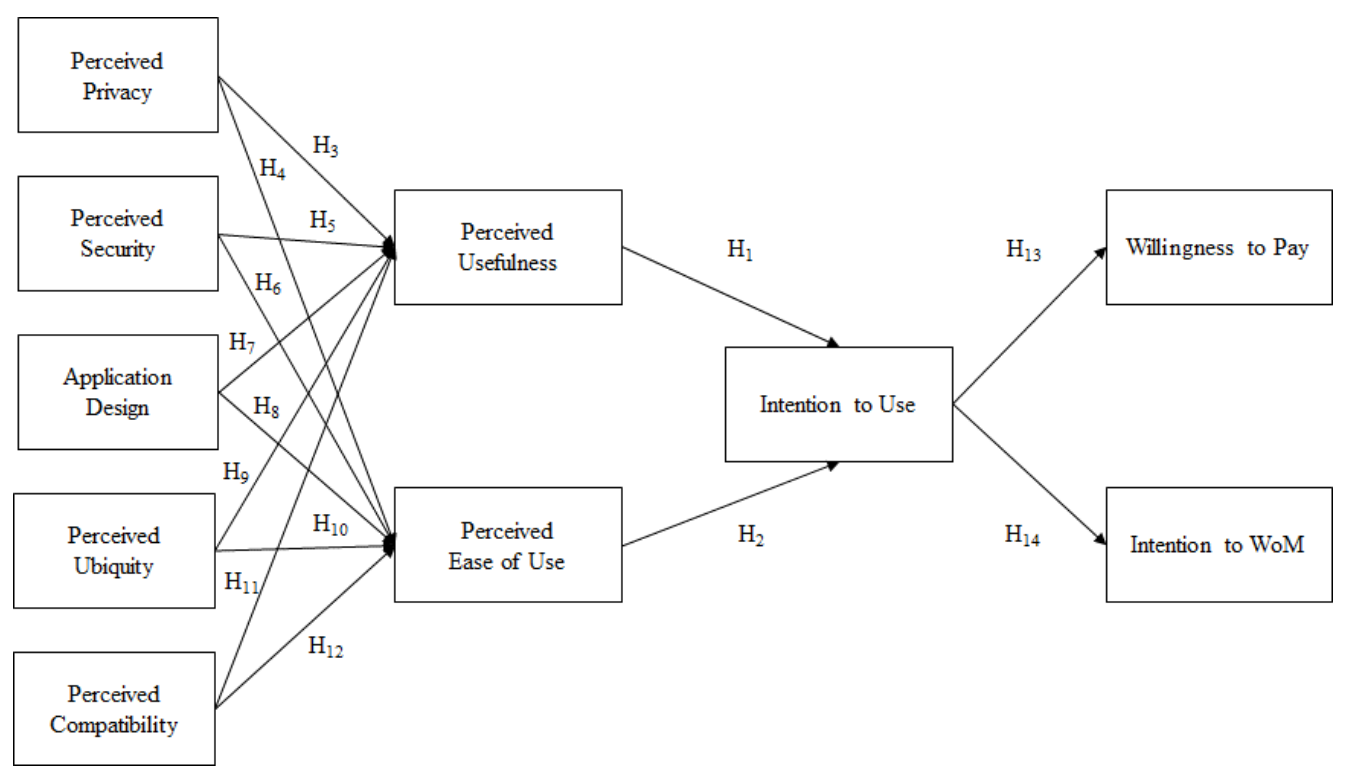

Figure 1: Conceptual Research Model 


\section{Research Methodology}

\subsection{Research Design}

The objective of this study is to identify the determinants (usefulness and ease of use) as well as the behavioral outcomes (willingness to pay and intention to WoM) of mobile app usage intention among Generation $\mathrm{Z}$ consumers. The participant group of the study is chosen among Generation $\mathrm{Z}$ members aged between 18-21, living in Istanbul and are familiar with mobile apps in different categories. The study is composed of three sub-studies each conducted in a different mobile add category context, namely entertainment, communication and social networking. The apps which were included in the study were among the most used ones by Turkish citizens. Total number of subjects who participated in all three studies was 345 . The number of participants in each sub-study and their corresponding demographic structure is summarized in Table 1.

Table 1. Demographic Composition of Participants

\begin{tabular}{|c|c|c|c|c|c|c|c|c|}
\hline \multirow[t]{2}{*}{ Characteristics } & \multicolumn{2}{|c|}{$\begin{array}{c}\text { App Category } \\
\text { (Entertainment) }\end{array}$} & \multicolumn{2}{|c|}{$\begin{array}{c}\text { App Category } \\
\text { (Communication) }\end{array}$} & \multicolumn{2}{|c|}{$\begin{array}{l}\text { App Category } \\
\text { (Networking) }\end{array}$} & \multicolumn{2}{|c|}{ Total } \\
\hline & $\mathrm{n}$ & $\%$ & $\mathrm{n}$ & $\%$ & $\mathrm{n}$ & $\%$ & $\mathrm{n}$ & $\%$ \\
\hline \multicolumn{9}{|l|}{ Gender } \\
\hline Male & 60 & 48.0 & 55 & 47.8 & 55 & 52.4 & 170 & 49.3 \\
\hline Female & 65 & 52.0 & 60 & 52.2 & 50 & 47.6 & 175 & 50.7 \\
\hline Total & 125 & 100.0 & 115 & 100.0 & 105 & 100.0 & 345 & 100.0 \\
\hline \multicolumn{9}{|l|}{ Occupation } \\
\hline Student & 75 & 60.0 & 60 & 52.2 & 55 & 52.4 & 190 & 55.1 \\
\hline Working & 50 & 40.0 & 55 & 47.8 & 50 & 47.6 & 155 & 44.9 \\
\hline Total & 125 & 100.0 & 115 & 100.0 & 105 & 100.0 & 345 & 100.0 \\
\hline
\end{tabular}

Three sub-studies were designed to identify the determinants of mobile app usage intention and its consequences in terms of willingness to pay and engage into WoM communication. A different category of mobile app, namely streaming music services, communication services, and finally social networking services, were employed in each of these sub-studies. A list of four branded mobile apps were presented to respondents in each sub-study and they were asked to choose one of these apps which they already know and use. In case when the participants couldn't find the app they use in the list, they were provided the opportunity to mention the app they use. Following their selection, they were asked to answer the questions taking into consideration the selected mobile app. The list of mobile apps provided in each category and the selection of respondents are provided in Table 2.

Table 2. Mobile App Categories, Listed Mobile Apps and Choices

\begin{tabular}{|c|c|c|c|c|c|}
\hline \multicolumn{2}{|c|}{ Entertainment } & \multicolumn{2}{c|}{ Communication } & \multicolumn{2}{c|}{ Social Networking } \\
\hline Mobile Application & $\mathrm{n}$ & Mobile Application & $\mathrm{n}$ & Mobile Application & $\mathrm{n}$ \\
\hline Apple Music & 34 & WhatsApp & 78 & Facebook & 25 \\
\hline Spotify & 62 & Messenger & 24 & Instagram & 31 \\
\hline Google Play Music & 24 & Skype & 13 & Tweeter & 8 \\
\hline Pulsar & 3 & Other & - & Snapchat & 41 \\
\hline Other & 2 & & & Other & - \\
\hline Total & 125 & Total & 115 & Total & 105 \\
\hline
\end{tabular}




\subsection{Scales of Variables}

All the scales employed in the study were taken from the studies in the corresponding literature. In line with the research model and hypotheses proposed, the determinants of perceived usefulness and ease of use, which are perceived privacy, perceived security, design characteristics, ubiquity and compatibility variables, were used in accordance with the scales employed and validated in the previous studies. The five items with five points Likert-Type scale for perceived privacy was taken from the study of Miyazaki \& Fernandez (2001). Perceived security is measured with the employment of a three items five points Likert Type scale developed and validated by Kumar et al. (2018). Authors reported a Cronbach's Alpha score of 0.80 which represents sufficient internal reliability of the scale. Mobile app design characteristics measuring the perception of consumers about the features and customization level of the mobile app is measured with the three items seven points Likert Type scale taken from the study of $\mathrm{Wu}$ (2014). Authors validated the scale and reported a sufficient level of reliability score exceeding 0.70 levels. The ubiquity factor was measured with the employment of three items five points Likert Type scale from Tojib and Tsarenko (2012) who taken and modified the scale from the study of Kim and Kim (2002). The authors validated the modified scale and reported a reliability score of 0.77 which is in an acceptable level. As the final proposed determinant of the perceived usefulness and ease of use, the scale for measuring the compatibility of mobile app, was borrowed from the study of Stocchi et al. (2019) who adapted and modified the scales from $\mathrm{Wu}$ and Wang (2005). The authors validated the scale and reported a reliability score of 0.73 which is again at an acceptable level. The scales for perceived usefulness and ease of use, both consisted of three items Likert Type scales, were borrowed from the study of Lee et al. (2007) and modified for the purpose of this study. Authors validated the scales and reported reliability scores of 0.86 and 0.92 for the scales, respectively. Finally, the intention to WoM and Willingness to pay scales, both two items and five points Likert Type scales, were adapted from the study of Stocchi et al. (2019) who developed and validated the scales. Authors did not report any reliability score for these scales.

The scales which are taken from the existing literature were adjusted and modified in compliance with the objectives of this study. Statements of the scales were modified in order to reflect the mobile app context and translated into Turkish language. These changes required to check and confirm for the validity and reliability of the scales employed in the study. In order to test and confirm the construct validity of the measurement model, a Confirmatory Factor Analysis (CFA) was conducted using IBM SPSS AMOS 26 software by including all factor items included in the study (Anderson \& Gerbing, 1988).

Testing of the measurement model for construct validity by CFA produced satisfactory levels of fit indices $(\chi 2 / \mathrm{DF}=1.629, \mathrm{CFI}=0.948, \mathrm{IFI}=0.949$, RMSEA $=0.071)$. The results are within the acceptable thresholds including CMIN/DF ratio below the threshold level of 3, CFI and IFI are above 0.9 level and RMSEA below 0.10 (Bagozzi \& Yi, 1990).

The standardized factor loadings of all variable items presented in Table 3 are at satisfactory levels and statistically significant. 
Table 3. PCA-Principal Component Analysis Results - Factor Loadings

\begin{tabular}{|c|c|c|c|c|c|}
\hline Variables & Items & $\begin{array}{c}\text { Standardized } \\
\text { Factor } \\
\text { Loadings }\end{array}$ & Variables & Items & $\begin{array}{c}\text { Standardized } \\
\text { Factor } \\
\text { Loadings }\end{array}$ \\
\hline \multirow{5}{*}{ Perceived Privacy } & PR1 & .767 & \multirow{2}{*}{$\begin{array}{c}\text { Perceived } \\
\text { Compatibility }\end{array}$} & COM1 & .962 \\
\hline & PR2 & .768 & & COM2 & 1.005 \\
\hline & PR3 & .712 & \multirow{3}{*}{$\begin{array}{l}\text { Perceived } \\
\text { Usefulness }\end{array}$} & USE1 & .858 \\
\hline & PR4 & .678 & & USE2 & .970 \\
\hline & PR5 & .703 & & USE3 & .995 \\
\hline \multirow{3}{*}{ Perceived Security } & SEC1 & .714 & \multirow{3}{*}{$\begin{array}{l}\text { Perceived Ease } \\
\text { of Use }\end{array}$} & EAS1 & .806 \\
\hline & SEC2 & .881 & & EAS2 & .907 \\
\hline & SEC3 & .660 & & EAS3 & 1.347 \\
\hline \multirow{3}{*}{ Perceived Design } & DES1 & .903 & \multirow{3}{*}{ Intention to Use } & USA1 & .935 \\
\hline & DES2 & .959 & & USA2 & .845 \\
\hline & DES3 & 1.011 & & USA3 & 1.001 \\
\hline \multirow{3}{*}{ Perceived Ubiquity } & UB1 & .875 & \multirow{2}{*}{$\begin{array}{l}\text { Willingness to } \\
\text { Pay }\end{array}$} & PUR1 & .914 \\
\hline & UB2 & .831 & & PUR2 & .974 \\
\hline & UB3 & .912 & $\begin{array}{l}\text { Intention to } \\
\text { WoM }\end{array}$ & WoM1 & .865 \\
\hline \multicolumn{3}{|c|}{ *All loadings are significant at .01 level. } & & WoM2 & .822 \\
\hline
\end{tabular}

Average variance extracted (AVE) values were calculated to check for convergent validity of scales. According to the calculated AVE values, all values were above the minimum acceptable level of 0.5 confirming the convergent validity of the scales (Byrne, 2010). In order to confirm the discriminant validity of the scales, square roots of AVE scores and the correlation between scales were compared and discriminant validity was confirmed. Moreover, in order to test the reliability of the scales, internal reliability (Cronbach $\alpha$ ) and composite reliability tests were conducted, and all scores were found to be above the acceptable minimum level of 0.5 (Fornell $\&$ Larcker, 1981). The test results and associated scores for validity and reliability checks are summarized in Table 4. 
Table 4. PCA Validity and Reliability Check Results

\begin{tabular}{|c|c|c|c|c|c|c|c|c|c|c|}
\hline Variables & 1 & 2 & 3 & 4 & 5 & 6 & 7 & 8 & 9 & 10 \\
\hline $\begin{array}{c}\text { Perceived } \\
\text { Privacv }\end{array}$ & $(.727)$ & & & & & & & & & \\
\hline $\begin{array}{c}\text { Perceived } \\
\text { Security }\end{array}$ & $-.526^{* *}$ & $(.758)$ & & & & & & & & \\
\hline $\begin{array}{l}\text { Perceived } \\
\text { Design }\end{array}$ & $-.424 * *$ & $.243^{* *}$ & $(.959)$ & & & & & & & \\
\hline $\begin{array}{l}\text { Perceived } \\
\text { Ubiquity }\end{array}$ & $-.322 *$ & $.247 * *$ & $.226^{*}$ & $(.873)$ & & & & & & \\
\hline $\begin{array}{c}\text { Perceived } \\
\text { Compatibility }\end{array}$ & $-.589 * *$ & $.308 * *$ & $.329 * *$ & $.183^{*}$ & $(.984)$ & & & & & \\
\hline $\begin{array}{l}\text { Perceived } \\
\text { Usefulness }\end{array}$ & $.497 * *$ & $-.352 * *$ & $-.264 * *$ & -.170 & .062 & $(.943)$ & & & & \\
\hline $\begin{array}{c}\text { Perceived Ease } \\
\text { of Use }\end{array}$ & $.699 * *$ & $-.452 * *$ & $-.365^{* *}$ & $-.251 * *$ & $-.236^{* *}$ & $.782 * *$ & (1.047) & & & \\
\hline $\begin{array}{l}\text { Intention to } \\
\text { Use }\end{array}$ & .059 & -.065 & .086 & -.097 & .084 & $.210^{*}$ & $.204 *$ & $(.929)$ & & \\
\hline $\begin{array}{c}\text { Willingness to } \\
\text { Pav }\end{array}$ & $.545^{* *}$ & $-.414 * *$ & $-.301 * *$ & $-.216^{*}$ & .054 & $.897 * *$ & $.860^{* * *}$ & $.272 * *$ & $(.944)$ & \\
\hline $\begin{array}{c}\text { Intention to } \\
\text { WoM }\end{array}$ & $.443^{* *}$ & $-.550^{*}$ & $-.314 * *$ & $-.287 * *$ & $-.269^{* * *}$ & $.267 * *$ & $.311^{* *}$ & -.077 & $.259 * *$ & (.844) \\
\hline $\begin{array}{l}\text { Composite } \\
\text { Reliabilitv }\end{array}$ & 7.848 & 7.799 & 9.971 & 7.906 & .983 & .960 & 1.032 & .950 & .943 & 7.832 \\
\hline AVE Scores & .528 & .574 & .919 & .763 & .968 & .889 & 1.096 & .863 & .892 & .712 \\
\hline Cronbach $\alpha$ & .876 & .764 & .962 & .891 & .983 & .920 & .834 & .726 & .942 & .831 \\
\hline \multicolumn{11}{|c|}{${ }^{*}$ Correlation is significant at .05 level. } \\
\hline cho & & & & & & & & & & \\
\hline
\end{tabular}

\section{Findings}

Study 1. Entertainment Category

The identification of the factors contributing to the mobile application adoption and its consequences in the entertainment category was made through the testing of the research model by employing Structural Equation Model with maximum likelihood estimation method. The evaluation of the structural regression model was made by checking the Goodness of fit indices. Goodness of fit indices include the absolute fit indices, $\chi^{2}$ statistic and the root mean square error of approximation (RMSEA), and, the relative goodness of fit indices, the comparative fit index (CFI) and the incremental fit index (IFI) (Akgün et al. 2014). The results and values of the fit indices confirm the fit of the model ( $\chi 2$ /DF 1.893, CFI 0.913, IFI 0.915, and RMSEA $0.085)$. The results of the structural equation model analysis including the direction and extent of the relationship between the variables are provided in Figure 2. 


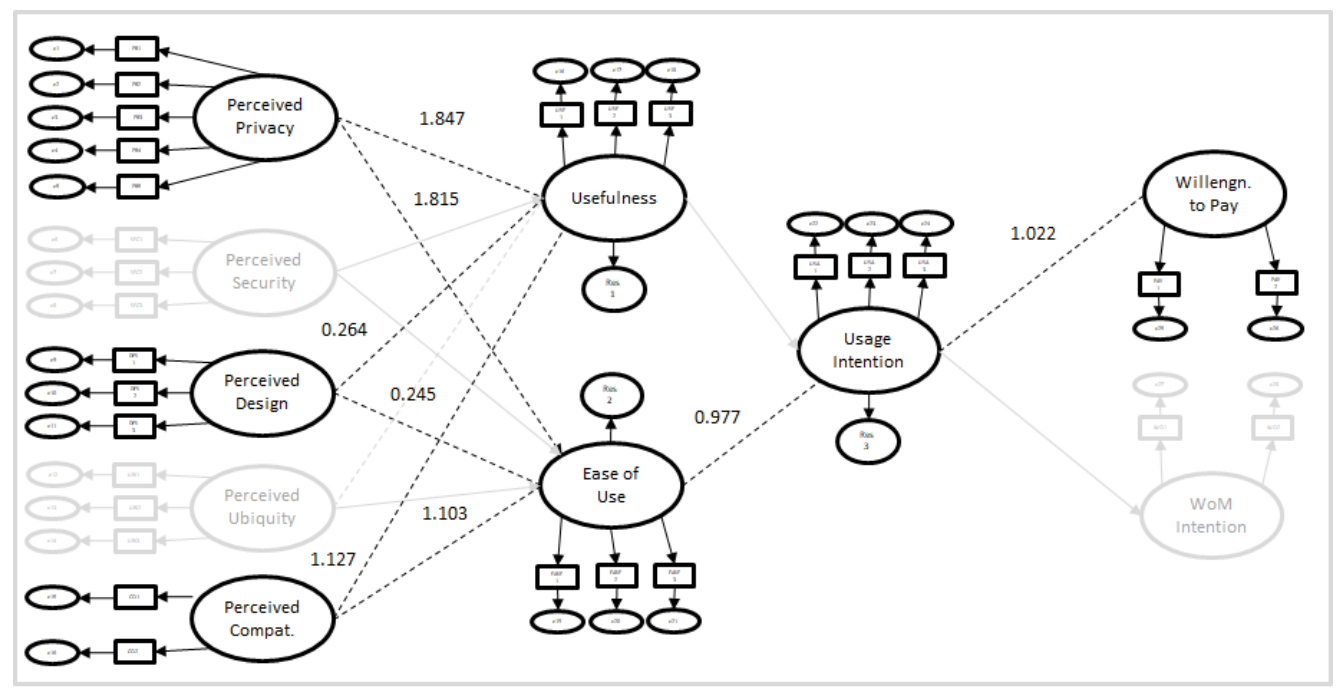

Notes: $\mathrm{X} 2 / \mathrm{DF}=1.893, \mathrm{CFI}=0.913, \mathrm{IFI}=0.915, \mathrm{RMSEA}=0.085$

Figure 2. Entertainment Category Results of the Structural Equation Model Analysis

Three of the five factors were identified as the determinants of perceived usefulness and ease of use regarding the mobile application in entertainment category. Perceived privacy was found to have a significant and positive effect on perceived usefulness $(\beta=1.847, \mathrm{p}<0.001)$ and ease of use $(\beta=1.815, \mathrm{p}<0.001)$. Similarly, perceived design was found to have a significant and positive effect on perceived usefulness $(\beta=0.264, \mathrm{p}=0.032)$ and ease of use $(\beta=0.245$, $\mathrm{p}<0.040$ ). Finally, perceived compatibility was found to have a significant and positive effect on perceived usefulness $(\beta=1.127, \mathrm{p}<0.001)$ and ease of use $(\beta=1.103, \mathrm{p}<0.001)$. Perceived security and perceived ubiquity are found to have no significant effect on perceived usefulness and ease of use in the entertainment mobile app category. In the light of these findings, $\mathrm{H}_{3}, \mathrm{H}_{4}$, $\mathrm{H}_{7}, \mathrm{H}_{8}, \mathrm{H}_{11}$ and $\mathrm{H}_{12}$ are supported and $\mathrm{H}_{5}, \mathrm{H}_{6}, \mathrm{H}_{9}, \mathrm{H}_{10}$ are not supported for the entertainment app category. Furthermore, usage intention is found to be affected by the ease of use perception of consumers in this category. Ease of use have a positive, strong and significant effect $(\mathrm{B}=$ 0.977, $\mathrm{p}=0.003$ ) on the usage intention of the mobile app. On the other hand, perceived usefulness is not found to be affective on the intention to use the mobile app. Thus, $\mathrm{H}_{2}$ is supported and $\mathrm{H}_{1}$ is not supported in the entertainment mobile add category. Table 5 includes the results of the hypothesis testing. 
Table 5. Entertainment Category Results of the Hypothesis Testing

\begin{tabular}{|c|l|c|c|c|c|c|}
\hline & \multicolumn{1}{|c|}{ Relationship } & $\begin{array}{c}\text { Regression } \\
\text { Coefficient }\end{array}$ & $\begin{array}{c}\text { Standardized } \\
\text { Beta }\end{array}$ & S.E. & C.R. & P \\
\hline $\mathrm{H}_{1}$ & Usefulness $\rightarrow$ Intention to Use &, 006 &, 038 &, 010 &, 561 &, 575 \\
\hline $\mathrm{H}_{2}$ & Ease of Use $\rightarrow$ Intention to Use &, 103 &, 977 &, 034 & 3,006 &, $003 *$ \\
\hline $\mathrm{H}_{3}$ & Privacy $\rightarrow$ Usefulness & 2,316 & 1,847 &, 416 & 5,562 &, $000^{* *}$ \\
\hline $\mathrm{H}_{4}$ & Privacy $\rightarrow$ Ease of Use & 3,158 & 1,815 &, 517 & 6,110 &, $000^{* *}$ \\
\hline $\mathrm{H}_{5}$ & Security $\rightarrow$ Usefulness &, 349 &, 347 &, 184 & 1,894 &, 058 \\
\hline $\mathrm{H}_{6}$ & Security $\rightarrow$ Ease of Use &, 404 &, 289 &, 237 & 1,709 &, 088 \\
\hline $\mathrm{H}_{7}$ & Design $\rightarrow$ Usefulness &, 185 &, 264 &, 086 & 2,146 &, $032 *$ \\
\hline $\mathrm{H}_{8}$ & Design $\rightarrow$ Ease of Use &, 276 &, 207 &, 144 & 1,923 &, 054 \\
\hline $\mathrm{H}_{9}$ & Ubiquity $\rightarrow$ Usefulness &, 274 &, 148 &, 195 & 1,402 &, 161 \\
\hline $\mathrm{H}_{10}$ & Ubiquity $\rightarrow$ Ease of Use &, 704 & 1,127 &, 107 & 6,555 &, $000^{* *}$ \\
\hline $\mathrm{H}_{11}$ & Compatibility $\rightarrow$ Usefulness &, 956 & 1,103 &, 130 & 7,335 &, $000^{* *}$ \\
\hline $\mathrm{H}_{12}$ & Compatibility $\rightarrow$ Ease of Use & 8,995 & 1,002 & 2,935 & 3,064 &, $002^{*}$ \\
\hline $\mathrm{H}_{13}$ & Intention to Use $\rightarrow$ Willingness to Pay &, 281 &, 911 & 1,925 &, 054 \\
\hline $\mathrm{H}_{14}$ & Intention to Use $\rightarrow$ Intention to WoM & 1,753 & & & \\
\hline$*$ Significant at .05 level. ** Significant at .01 level. & &, 054 &, $040 *$ \\
\hline
\end{tabular}

Study 2. Communication Category

As it is applied in the previous category, the identification of the factors contributing to the mobile application adoption and its consequences in the communication category was made through the testing of the research model by employing Structural Equation Model with maximum likelihood estimation method. The results and values of the fit indices confirm the fit of the model ( $\chi 2$ /DF 1.995, CFI 0.901, IFI 0.903, and RMSEA 0.093). The results of the structural equation model analysis including the direction and extent of the relationship between the variables are provided in Figure 3. 


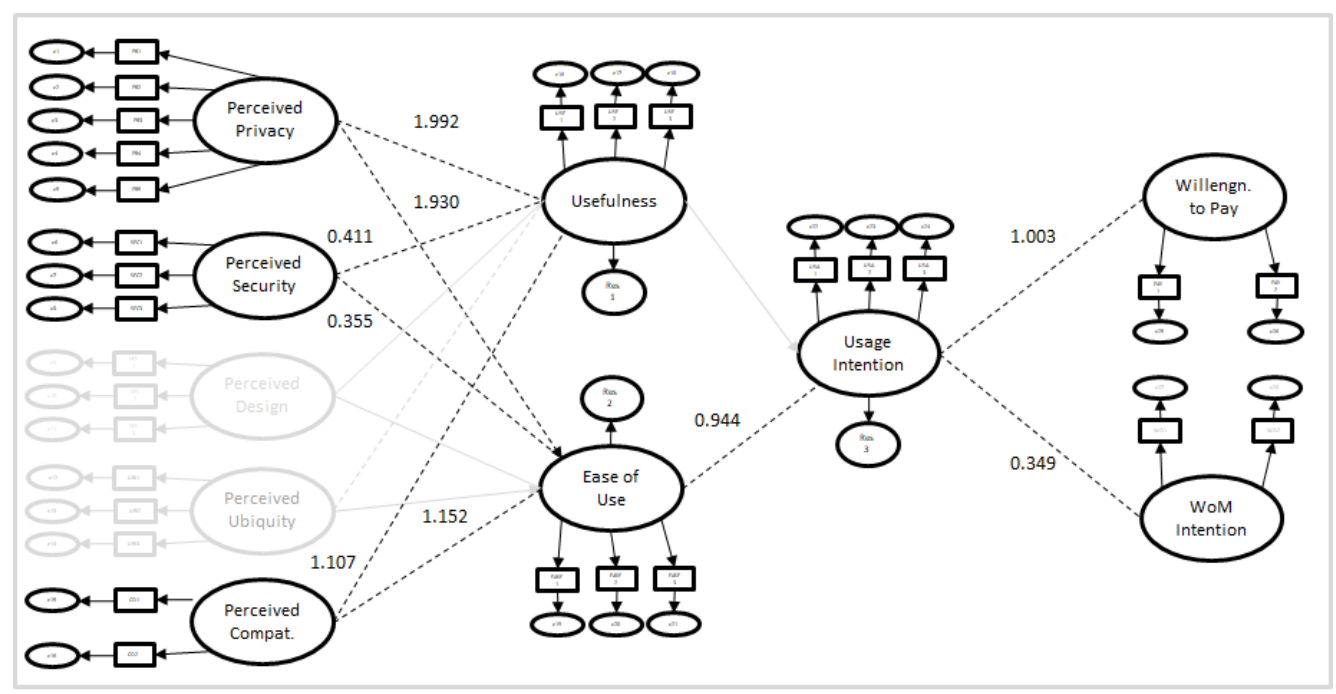

Notes: $\mathrm{X} 2 / \mathrm{DF}=1.995, \mathrm{CFI}=0.901, \mathrm{IFI}=0.903, \mathrm{RMSEA}=0.093$

Figure 3. Communication Category Results of the Structural Equation Model Analysis

Three of the five factors were identified as the determinants of perceived usefulness and ease of use regarding the mobile application in communication category. Perceived privacy was found to have a significant and positive effect on perceived usefulness $(\beta=1.992, p<0.001)$ and ease of use $(\beta=1.930, p<0.001)$. Similarly, perceived security was found to have a significant and positive effect on perceived usefulness $(\beta=0.411, \mathrm{p}=0.026)$ and ease of use $(\beta=0.355$, $\mathrm{p}<0.036$ ). Finally, perceived compatibility was found to have a significant and positive effect on perceived usefulness $(\beta=1.107, \mathrm{p}<0.001)$ and ease of use $(\beta=1.152, \mathrm{p}<0.001)$. Perceived design and perceived ubiquity are found to have no significant effect on perceived usefulness and ease of use in the communication mobile app category. In the light of these findings, $\mathrm{H}_{3}$, $\mathrm{H}_{4}, \mathrm{H}_{5}, \mathrm{H}_{6}, \mathrm{H}_{11}$ and $\mathrm{H}_{12}$ are supported and $\mathrm{H}_{7}, \mathrm{H}_{8}, \mathrm{H}_{9}, \mathrm{H}_{10}$ are not supported for the communication app category. Furthermore, usage intention is found to be affected by the ease of use perception of consumers in this category. Ease of use have a positive, strong and significant effect $(\beta=0.944, \mathrm{p}<0.001)$ on the usage intention of the mobile app. On the other hand, perceived usefulness is not found to be affective on the intention to use the mobile add. Parallel to the findings in the entertainment category, $\mathrm{H}_{2}$ is supported and $\mathrm{H}_{1}$ is not supported in the communication mobile add category. Table 6 includes the results of the hypothesis testing. 
Table 6. Communication Category Results of the Hypothesis Testing

\begin{tabular}{|c|c|c|c|c|c|c|}
\hline & Relationship & $\begin{array}{l}\text { Regression } \\
\text { Coefficient }\end{array}$ & $\begin{array}{c}\text { Standardized } \\
\text { Beta }\end{array}$ & S.E. & C.R. & $P$ \\
\hline $\mathrm{H}_{1}$ & Usefulness $\rightarrow$ Intention to Use & ,011 &, 069 &, 012 &, 942 &, 346 \\
\hline $\mathrm{H}_{2}$ & Ease of Use $\rightarrow$ Intention to Use & ,104 & ,944 &, 031 & 3,318 &, $000 * *$ \\
\hline $\mathrm{H}_{3}$ & Privacy $\rightarrow$ Usefulness & 2,151 & 1,992 &, 370 & 5,812 &, $000 * *$ \\
\hline $\mathrm{H}_{4}$ & Privacy $\rightarrow$ Ease of Use & 2,974 & 1,930 & ,462 & 6,437 &, $000 * *$ \\
\hline $\mathrm{H}_{5}$ & Security $\rightarrow$ Usefulness &, 360 & ,411 &, 161 & 2,233 &, $026^{*}$ \\
\hline $\mathrm{H}_{6}$ & Security $\rightarrow$ Ease of Use & ,433 & ,355 &, 211 & 2,100 &, $036^{*}$ \\
\hline $\mathrm{H}_{7}$ & Design $\rightarrow$ Usefulness &, 143 & ,215 &, 081 & 1,756 & ,079 \\
\hline $\mathrm{H}_{8}$ & Design $\rightarrow$ Ease of Use & ,196 & ,207 &, 112 & 1,748 & ,080 \\
\hline $\mathrm{H}_{9}$ & Ubiquity $\rightarrow$ Usefulness & ,259 & ,208 &, 142 & 1,827 & ,068 \\
\hline $\mathrm{H}_{10}$ & Ubiquity $\rightarrow$ Ease of Use & ,215 &, 121 & ,196 & 1,096 & ,273 \\
\hline $\mathrm{H}_{11}$ & Compatibility $\rightarrow$ Usefulness & ,685 & 1,152 &, 110 & 6,256 &, $000 * *$ \\
\hline $\mathrm{H}_{12}$ & Compatibility $\rightarrow$ Ease of Use & ,940 & 1,107 &, 136 & 6,897 &, $000 * *$ \\
\hline $\mathrm{H}_{13}$ & Intention to Use $\rightarrow$ Willingness to Pay & 8,335 & 1,003 & 2,440 & 3,416 &, $000 * *$ \\
\hline $\mathrm{H}_{14}$ & Intention to Use $\rightarrow$ Intention to WoM & 2,191 & ,349 & ,948 & 2,312 &, $021 *$ \\
\hline
\end{tabular}

Study 3. Networking Category

As it is applied in the previous category, the identification of the factors contributing to the mobile application adoption and its consequences in the networking category was made through the testing of the research model by employing Structural Equation Model with maximum likelihood estimation method. The results and values of the fit indices confirm the fit of the model ( $\chi 2 /$ DF 1.742, CFI 0.919, IFI 0.921, and RMSEA 0.084). The results of the structural equation model analysis including the direction and extent of the relationship between the variables are provided in Figure 4. 


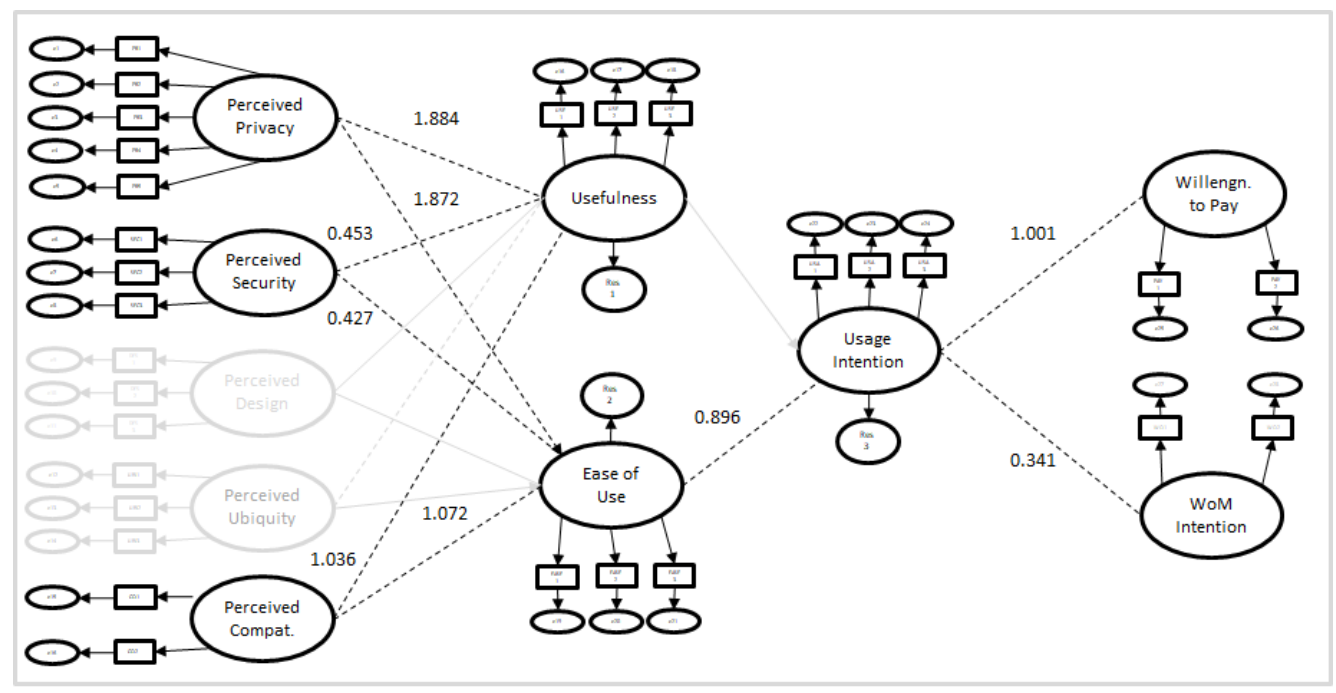

Notes: $\chi 2 / D F=1.742, C F I=0.919, I F I=0.921$, RMSEA $=0.084$

Figure 4. Networking Category Results of the Structural Equation Model Analysis

Three of the five factors were identified as the determinants of perceived usefulness and ease of use regarding the mobile application in networking category. Perceived privacy was found to have a significant and positive effect on perceived usefulness $(\beta=1.884, \mathrm{p}<0.001)$ and ease of use $(\beta=1.872, p<0.001)$. Similarly, perceived security was found to have a significant and positive effect on perceived usefulness $(\beta=0.453, p=0.026)$ and ease of use ( $\beta=0.427$, $\mathrm{p}<0.036)$. Finally, perceived compatibility was found to have a significant and positive effect on perceived usefulness $(\beta=1.036, p<0.001)$ and ease of use $(\beta=1.072, p<0.001)$. Perceived design and perceived ubiquity are found to have no significant effect on perceived usefulness and ease of use in the networking mobile app category. In the light of these findings, $\mathrm{H}_{3}, \mathrm{H}_{4}, \mathrm{H}_{5}$, $\mathrm{H}_{6}, \mathrm{H}_{11}$ and $\mathrm{H}_{12}$ are supported and $\mathrm{H}_{7}, \mathrm{H}_{8}, \mathrm{H}_{9}, \mathrm{H}_{10}$ are not supported for the networking app category. Furthermore, usage intention is found to be affected by the ease of use perception of consumers in this category. Ease of use have a positive, strong and significant effect ( $\beta=0.896$, $\mathrm{p}<0.001$ ) on the usage intention of the mobile app. On the other hand, perceived usefulness is not found to be affective on the intention to use the mobile add. Parallel to the findings in the previous two categories, $\mathrm{H}_{2}$ is supported and $\mathrm{H}_{1}$ is not supported in the networking mobile add category. Table 7 includes the results of the hypothesis testing. 
Table 7. Networking Category Results of the Hypothesis Testing

\begin{tabular}{|c|c|c|c|c|c|c|}
\hline & Relationship & $\begin{array}{l}\text { Regression } \\
\text { Coefficient }\end{array}$ & $\begin{array}{c}\text { Standardized } \\
\text { Beta }\end{array}$ & S.E. & C.R. & $P$ \\
\hline $\mathrm{H}_{1}$ & Usefulness $\rightarrow$ Intention to Use & ,016 &, 117 &, 011 & 1,499 & ,134 \\
\hline $\mathrm{H}_{2}$ & Ease of Use $\rightarrow$ Intention to Use & 086 & ,896 &, 030 & 2,823 &, $005^{*}$ \\
\hline $\mathrm{H}_{3}$ & Privacy $\rightarrow$ Usefulness & 2,016 & 1,884 &, 353 & 5,704 &, $000 * *$ \\
\hline $\mathrm{H}_{4}$ & Privacy $\rightarrow$ Ease of Use & 2,866 & 1,872 &, 458 & 6,264 &, $000 * *$ \\
\hline $\mathrm{H}_{5}$ & Security $\rightarrow$ Usefulness & 411 & ,453 &, 181 & 2,274 &, $023 *$ \\
\hline $\mathrm{H}_{6}$ & Security $\rightarrow$ Ease of Use &, 555 & ,427 &, 247 & 2,244 &, $025^{*}$ \\
\hline $\mathrm{H}_{7}$ & Design $\rightarrow$ Usefulness & ,068 & ,097 & ,079 &, 856 & ,392 \\
\hline $\mathrm{H}_{8}$ & Design $\rightarrow$ Ease of Use & 067 & 069 &, 110 &, 620 &, 535 \\
\hline $\mathrm{H}_{9}$ & Ubiquity $\rightarrow$ Usefulness & ,205 & ,156 &, 144 & 1,420 &, 156 \\
\hline $\mathrm{H}_{10}$ & Ubiquity $\rightarrow$ Ease of Use &, 172 & ,092 & ,200 &, 859 & ,390 \\
\hline $\mathrm{H}_{11}$ & Compatibility $\rightarrow$ Usefulness & ,632 & 1,072 &, 103 & 6,132 &, $000 * *$ \\
\hline $\mathrm{H}_{12}$ & Compatibility $\rightarrow$ Ease of Use & ,874 & 1,036 &, 131 & 6,687 &, $000 * *$ \\
\hline $\mathrm{H}_{13}$ & Intention to Use $\rightarrow$ Willingness to Pay & 10,007 & 1,001 & 3,465 & 2,888 &, $004 *$ \\
\hline $\mathrm{H}_{14}$ & Intention to Use $\rightarrow$ Intention to WoM & 2,520 & ,341 & 1,229 & 2,049 &, $040 *$ \\
\hline
\end{tabular}

\section{Discussion and Practical Implications}

The objectives of this study were to identify the determinants of perceived usefulness and ease of use, the effect of these perceptions on the usage intentions and the consequences of usage intention in terms of willingness to pay and engagement into WoM activity in different categories of mobile apps considered and used by Generation $\mathrm{Z}$ consumers. The results of the analysis for three types of mobile app categories, namely Entertainment, Communication and Networking, confirmed that the perceptions related to the several mobile app characteristics were effective on the formation of perceptions regarding the usefulness and ease of use of these apps. Dependent on the type of app category, all proposed determinants including perceived privacy, perceived security, perceived design, perceived compatibility but excluding perceived ubiquity, were found to be effective on both perceived usefulness and ease of use. Perceived privacy, which measured the perception of consumers regarding their control over the personal information shared while using the app, was found to be effective on both usefulness and ease of use perceptions regarding the app. On the other hand, perceived security, which measured the perceptions of consumers regarding the protection and safety of their sensitive data and information while using the app, was also found to be effective on both perceived usefulness and ease of use. When perceived privacy and security increases, consumers perceive the mobile apps more useful and easier to use. 
Previous studies reported both significant (Polasik \& Wisniewski, 2008; Lallmahamood, 2007; Stochhi et al. 2019) and insignificant (Pikkarainen et al. 2004) results for the effect of these determinants on the perceived usefulness and ease of use of the mobile apps. This result is supported by the similar significant findings of other studies in the literature. However, the type of mobile app category influences the effects of both perceived privacy and perceived security. Perceived privacy is found to be effective on perceived usefulness and ease of use in all three types of mobile app categories. This effect is found to be much stronger in the communication app category since the essence of the functionality in this category is sharing information with other parties. On the other hand, perceived security is found to be effective on perceived usefulness and ease of use in two of the three types of mobile app categories. The effect of perceived security was significant and positive on the communication and networking app categories. However, there were no significant effect of perceived security on perceived usefulness and ease of use in the entertainment app category. The third factor proposed in the research model, application design, which measured the perception of consumers regarding the app features provided as well as customization options, was found to be effective both on perceived usefulness and ease of use. These results are supported by the similar significant findings of other studies in the literature (Chiu \& Yang, 2016; Stochhi et al. 2019). However, the type of mobile app category influences its effect on perceived usefulness and ease of use. Perceived design was only found to be significantly influencing the perceptions of consumers in the entertainment app category. Considering the requirement of higher level of customization options in the entertainment category apps, this result was expected. Surprisingly, the results confirmed that Generation $\mathrm{Z}$ consumers did not place any value for the design performance in communication and networking app categories. This may be due to the limited feature and customization requirements of these types of app categories compared to the entertainment category apps. Another factor proposed in the research model, perceived compatibility, which involves the functionality of the app in the device without any problems, is also found to be effective on the perceived usefulness and ease of use. The findings of previous studies, which reported the significant influence of perceived compatibility on the perception of usefulness and ease of use, are once more confirmed by the results of this study (Kang et al. 2015; Stochhi et al. 2019). As expected, this effect is found significant in all types of mobile app categories since compatibility is a major issue in the functionality. Finally, contrary to previous findings in the literature (Tojib \& Tsarenko, 2012; Stochhi et al. 2019), perceived ubiquity, which involves the perception of consumers regarding the freedom of usage of the app whenever and wherever they want, is found to have no significant effect on the perceived usefulness and ease of use. One of the contributions of this study is the conclusion that different mobile app categories require different types of features in order to be perceived as useful and easy to use.

A second objective of this study was to measure the effect of perceived usefulness and ease of use on the Generation Z's intention to use the mobile app in three different app categories. Results of the study confirmed that perceived ease of use significantly affects the intention to use the mobile app in all three app categories. The strongest effect among three app categories was found in the entertainment category. Previous studies report contradictory and inconclusive results on the effect of perceived ease of use on the adoption of mobile apps, as some studies reported significant effects (Natarajan et al. 2017) while others did not (Koenig et al. 2015; Dai \& Palvia, 2009). 
This study reports significant effect of perceived ease of use on the adoption of mobile apps in categories and confirms that this relationship needs further investigation in future studies. On the other hand, perceived usefulness is found to have no significant effect on the intention to use on all three app categories. This finding contradicts with the results of the previous studies which report significant effects on the intention to use the app (Hur et al. 2017; Natarajan et al. 2017). The insignificant effect of perceived usefulness on purchase intention makes the findings in the existing literature inconclusive due to the contradictory results reported including this study. Thus, this relationship too needs further investigation in the future studies.

A third and final objective of this study was to measure the effect of intention to purchase on both willingness to pay for the app services and intention to engage in WoM activity. The intention to use the mobile app was found to be an effective determinant of the willingness to pay for the app in all three app categories and the strongest effect was found in entertainment category. This finding was expected based on the theoretical framework (Werner, 2004), the relationship between intention and actual behavior (Albarracin et al. 2011) as well as previous findings (Stochhi et al. 2019). The intention to use was also found effective on the intention to engage in WoM activity of Generation Z. This finding was expected based on the theoretical framework (Thibaut \& Kelley, 1959) as well as previous parallel findings in the literature (Stocchi et al. 2019; Xu et al. 2015). This significant effect was reported in two of the three mobile app categories, namely communication and networking apps. The findings of this study reported no significant effects in the entertainment category. This can be explained based on the networking effect needs of communication and networking app categories. Both applications need to be widely used by user community and reach at the critical number of users in order to be an effective tool for communication and networking. Thus, consumers may need to engage in WoM activity when they intend to use the apps to bring their close circle of acquaintances into the same platform. This necessity is not valid in the entertainment category.

The findings in this study yield some managerial implications which need to be elaborated in detail. First, when we consider the factors which influence app usage intention of Generation Z consumers, ease of use becomes an important determinant in three types of app categories used in this study (entertainment, communication, networking). Thus, Generation $\mathrm{Z}$ consumers attribute value to user friendly apps which provide simple functionality, ease of learning and gaining mastership. When developing apps for their brands, managers should take into consideration the sensitivity about the ease of use for Generation $\mathrm{Z}$ consumers. On the other hand, several factors contribute to the perception of ease of use in different app categories. Perceived privacy is an important determinant of perceived ease of use in all three types of app categories. As the perceived privacy involves the perception of consumers regarding their control over the personal information shared while using the app, managers need to assure consumers that the app they are using respects their privacy and provides necessary controls to consumer. Managers need to develop and implement their digital marketing communications message strategy taking into consideration this requirement. A second important and more technical factor, which affects the perception of ease of use in all three types of app categories is perceived compatibility. Perceived compatibility involves the functioning of the app in the device without any problem. This result shows that Generation $\mathrm{Z}$ consumers do not have any tolerance for incompatible apps with their mobile devices and respective operating systems. Thus, technically speaking, managers need to make sure that the app is bug free and functions without any problems following the app version updates as well as operating system updates. 
A third important factor influencing the perceived ease of use is the perceived security, which is found to be effective in communication and networking app categories. As the security perception involves perceptions of consumers regarding the protection of their sensitive data and information while using the app, the results confirm that Generation $\mathrm{Z}$ consumers are sensitive to data safety especially when they use apps for communication and networking purposes. Thus, managers of brands which provide communication and networking apps, need to assure consumers that the app they are using provide the required data security standards to protect their personal data against the unauthorized access attempts from third-party users. Managers need to develop and implement their digital marketing communications message strategy in line with this requirement. The fourth factor which influence the perception of ease of use is the design of the app. This factor is found to be effective in entertainment category and lead us to conclude that when Generation $\mathrm{Z}$ consumers evaluate an app in the entertainment category such as music streaming services, the design of the app is an important factor to generate ease of use perceptions which in turn is expected to boost usage intention. Thus, managers who develop apps in this category should rely on consumer research and user tests before launching the apps in order to reach at an understanding of user sensitivities and necessities in app features as well as customization options. Whatever is the category of the app, increasing the perception of ease of use will lead to higher levels of usage intention and this will lead to willingness to pay additional services provided by the app. Thus, managers should understand the critical success factors in generating strong perceptions in privacy, security, design and compatibility depending on the app category and consequently support strong intention to use which eventually leads to willingness to pay. This will also lead to generate intention to engage in WoM activities of consumers in communication and entertainment app categories, which is vital for generating and speeding up the network effect.

\section{Limitations and Suggestions for Future Research}

As the study identified the determinants as well as consequences of mobile app usage intention of Generation $\mathrm{Z}$ consumers, the study was limited to three app categories including entertainment, communication and networking. This limits the generalizability of the findings to all types of mobile apps. Thus, future studies may include other types of categories and contribute to the generalizability. Moreover, this study involved only Generation $\mathrm{Z}$ consumers which also limits the generalizability to all consumer generations. Thus, future studies may implement a comparative approach among different generations to contribute to the generalizability of the findings. Another limitation of the study which leads to generalizability issue is related with the geographical as well as cultural coverage since the research was conducted in Turkey. Future studies may also consider investigating the determinants and consequences of mobile app usage intention of Generation $\mathrm{Z}$ consumers in a cross-country context. One another limitation of the study derives from the sampling methodology. A convenience sampling was employed in the study and this may result in some weaknesses regarding the representative power of the sample. 


\section{References}

Akgün, A. E., Ince, H., Imamoğlu, S., Keskin, H., and Kocoğlu, I. (2014). The mediator role of learning capability and business innovativeness between total quality management and financial performance. International Journal of Production Research, 52(3), 888-901.

Albarracin, D., Johnson, B. T., Fishbein, M. and Muellerleile, P. A. (2001). Theories of reasoned action and planned behavior as models of condom use: A meta-analysis. Psychological Bulletin, 127, 142-161.

Altuntuğ, N. (2012). Kuşaktan Kuşağa Tüketim Olgusu ve Geleceğin Tüketici Profili. Organizasyon ve Yönetim Bilimleri Dergisi, 4(1), 203-212.

Anderson, J. and Gerbing, D. W. (1988). Structural Equation Modeling in Practice: A Review and Recommended Two-Step Approach. Psychological Bulletin, 103(3), 411-423.

Arndt, J. A. (1967). Word of Mouth Advertising. New York: Advertising Research Foundation.

Arts, J. W. C., Frambach, R. T., and Bijmolt, T. H. A. (2011). Generalizations on consumer innovation adoption: A meta-analysis on drivers of intention and behavior. International Journal of Research in Marketing, 28, 134-144.

Bagozzi, R. P., and Yi, Y. (1990). Assessing Method Variance in Multitrait-Multimethod Matrices: The Case of Self-Reported Affect and Perceptions at Work. Journal of Applied Psychology, 75(1), 547-560.

Bansal, H.S. and Voyer, P.A. (2000). Word-of-mouth processes within a service purchase decision context. Journal of Service Research 3(2), 166-77.

Barford, I. N. and Hester, P.T. (2011). Analysis of Generation Y Workforce Motivation Using Multiattribute Utility Theory. FT BELVOIR VA: Defense Acquisition University.

Benítez, L.F. and Martinez, B.A. (2015). The effects mobile of applications as a marketing tool in airport infrastructure and airlines. International Journal of Leisure and Tourism Marketing, 4(3/4), 222-240.

Belch. G. E. and Belch. M. A. (2003). Advertising and Promotion an Integrated Marketing Communications Perspective. New York: McGraw-Hill.

Bellman, S., Potter, R. F., Treleaven-Hassard, S., Robinson, J. A. and Varan, D. (2011). The Effectiveness of Branded Mobile Phone Apps. Journal of Interactive Marketing, 25(4), 191- 200.

Bone, P.F. (1995). Word-of-mouth effects on short-term and long-term product judgments. Journal of Business Research, 32(3), 213-223.

Brown, J. J., and Reingen, P. H. (1987). Social ties and word-of-mouth referral behavior. Journal of Consumer Research, 14, 350-362.

Byrne, B. M. (2010). Structural Equation Modeling with AMOS. New York: Routledge Taylor \& Francis Group.

Chan, H. (2019). Generation Z: The Disrupters of Tomorrow. MyCommerce. Accessed: 27.05. 2019. https://www.mycommerce.com/generation-z-the-disrupters-of-tomorrow/.

Chiu, C.C. \& Yang, H.E. (2016). The Impact of Website Design Features on Behavioral Intentions. International Journal of Scientific and Technology Research Volume, 5(9), 71-78.

Cho, N. and Park, S. (2001). Development of electronic commerce user - consumer satisfaction index (ECUSI) for internet shopping. Industrial Management and Data Systems, 101(8), 400-405.

Crabbe M, Standing C, Standing S and Karjaluoto, H (2009). An adoption model for mobile banking in Ghana. International Journal of Mobile Communications, 7(5), 515-543.

Dai, H., and Palvia, P.C. (2009). Mobile commerce adoption in China and the United States: a cross-cultural study. DATA BASE, 40, 43-61. 
Darden W.R. and Reynolds F.D. (1971). The Multidimensionality of Fashion Innovation, in SV - Proceedings of the Second Annual Conference of the Association for Consumer Research, eds. David M. Gardner, College Park, MD: Association for Consumer Research, 452-458.

Davis, F. D. (1989). Perceived usefulness, perceived ease of use, and user acceptance of information technology. MIS Quarterly, 13(3), 319-339.

DeLone, W.H. and McLean, E.R. (1992). Information systems success: the quest for the dependent variable. Information Systems Research, 3(1), 60-95.

Eastman, J. K., and Liu, J. (2012). The impact of generational cohorts on status consumption: an exploratory look at generational cohort and demographics on status consumption. Journal of Consumer Marketing, 29(2), 93-102.

e-Marketer. (2018). More Millennials Gen Z Are Using Social Apps. Accessed: 05.06.2019. https://www.emarketer.com/content/more-millennials-gen-z-are-using-social-apps.

Fornell, C. and Larcker, D. (1981). Evaluating Structural Equation Models with Unobservable Variables and Measurement Error. Journal of Marketing Research, 18(1): 39-50.

Gurau, C. (2012). A life-stage analysis of consumer loyalty profile: comparing Generation X and Millennial consumers. Journal of Consumer Marketing, 29(2), 103-113.

Hausenblas, H. A., Caron, A. V. and Mack, D. E. (1997). Application of the theories of reasoned action and planned behavior to exercise behavior: A meta-analysis. Journal of Sport and Exercise Psychology, 19, 36-51.

Hewlett, S. A., Sherbin, L., and Sumberg, K. (2009). How Gen Y and Boomers will reshape your agenda. Harvard Business Review, 87(7-8), 71-6.

Hur, H.J., Lee, H.K., and Choo, H.J. (2017). Understanding usage intention in innovative mobile app service: Comparison between millennial and mature consumers. Computers in Human Behavior, 73, 353-361.

Jackson, V., Stoel, L. and Brantley, A. (2011). Mall attributes and shopping value: differences by gender and generational cohort. Journal of Retailing and Consumer Services, 18(1), $1-9$.

Kang, J.M., Mun, J.M., and Johnson, K.K.P. (2015). In-store mobile usage: Downloading and usage intention toward mobile location-based retail apps. Computers in Human Behavior, 46, 210-217.

Kim, J. (2012). The Effect of Design Characteristics of Mobile Applications on User Retention: An Environmental Psychology Perspective. AMCIS 2012 Proceedings, 13, 1-9.

Kim, S. and Garrison, G. (2009). Investigating mobile wireless technology adoption: an extension of the technology acceptance model. Information Systems Frontiers, 11(3), 323-333.

Kim H. and Kim J. (2002). An empirical research on important factors of mobile internet usage. Journal of MIS Research, 12(3), 90-113.

Koenig-Lewis, N., Marquet, M., Palmer, A. and Zhao, A.L. (2015). Enjoyment and social influence: predicting mobile payment adoption. The Service Industries Journal, 35(10), $1-18$.

Krishnan, K.S.T., and How, L.K. (2016). The Effect of Mobile Apps on Gen Z's Intention to Download Apps in Malaysia. International Journal of Advanced and Multidisciplinary Social Science, 2(3), 51-60.

Kumar, A., Adlakaha, A., and Mukherjee, K. (2018). The effect of perceived security and grievance redressal on continuance intention to use M-wallets in a developing country. International Journal of Bank Marketing, 36 (7), 1170-1189. 
Lallmahamood, M. (2007). An Examination of Individual's Perceived Security and Privacy of the Internet in Malaysia and the Influence of This on Their Intention to Use ECommerce: Using an Extension of the Technology Acceptance Model. Journal of Internet Banking and Commerce, 12(3), 1-26.

Lee, S. (2009). Mobile internet services from consumers' perspectives. International Journal of Human-Computer Interaction, 25(5), 390-413.

Lee, I., Choi, B., Kim, J. and Hong, S-J. (2007). Culture-Technology Fit: Effects of Cultural Characteristics on the Post-Adoption Beliefs of Mobile Internet Users. International Journal of Electronic Commerce, 11(4), 11-51.

Looney, C.A., Jessup, L.M., and Valacich, J.S. (2004). Emerging Business Models for Mobile Brokerage Services. Communications of the ACM, 47(6), 71-77.

Lyons, S. T., Duxbury, L., and Higgins, C. (2007). An empirical assessment of generational differences in basic human values. Psychological reports,101(2), 339-352.

Martin, C. A., and Turley, L. W. (2004). Malls and consumption motivation: an exploratory examination of older Generation Y consumers. International Journal of Retail \& Distribution Management, 32(10), 464-475.

McCrindle, M. and Wolfinger, E. (2010). The ABC of XYZ: Understanding the Global Generations. Sydney: University of New South Wales Press.

Meuter, M. L., Bitner, M. J., Ostrom, A. L., and Brown, S. W. (2005). Choosing among alternative service delivery modes: An investigation of customer trial of self-service technologies. Journal of Marketing, 69(2), 61-83.

Miyazaki, A.D. and Fernandez, A. (2001). Consumer perceptions of privacy and security risks for online shopping. Journal of Consumer Affairs, 35(1), 27-44.

Natarajan, T., Balasubramanian, S.A. and Kasilingam, D.L. (2017). Understanding the intention to use mobile shopping applications and its influence on price sensitivity. Journal of Retailing and Consumer Services, 37, 8-22.

Nikkhah, H.R., Balapour, A., and Sabherwal, R. (2018). Mobile Applications Security: Role of Privacy. Proceedings of Twenty-fourth Americas Conference on Information Systems, New Orleans, 1-5.

Norum, P.S. (2003). Examination of generational differences in household apparel expenditures. Family and Consumer Sciences Research Journal, 32(1), 52-75.

Porter, C. E., and Donthu, N. (2006). Using the technology acceptance model to explain how attitudes determine Internet usage: The role of perceived access barriers and demographics. Journal of Business Research, 59(9), 999-1007.

Queitzsch, S. (2015). Five generation juggle. Johnston \& Goldsmith, Think Paper. Accessed: 25.05.2019.https://static1.squarespace.com/static/5859fc13197aeabb8cf959f0/t/58a50 de1d482e94691deda4e/1487212012446/Five+Generation+Juggle.pdf

Reisenwitz, T. and Iyer, R. (2007). A comparison of younger and older baby boomers: investigating the viability of cohort segmentation. Journal of Consumer Marketing, 24(4), 202-213.

Rogers, E. M. (1962). Diffusion of Innovations, New York: The Free Press.

Rohm, A.J., Gao, T., and Sultan, F. (2012). Brand in the hand: A cross-market investigation of consumer acceptance of mobile marketing. Business Horizons, 55, 485-493.

Roy, S. and Moorthi, Y.L.R. (2017). Technology readiness, perceived ubiquity and Mcommerce adoption: The moderating role of privacy. Journal of Research in Interactive Marketing, 11(3), 268-295.

Sarker, S. and Wells, J. D. (2003). Understanding mobile handheld device use and adoption. Communications of the ACM, 46, 35-40.

Sathye, M. (1999). Adoption of Internet banking by Australian consumers: an empirical investigation. International Journal of Bank Marketing, 17(7), 324-34. 
Schlossberg, M. (2016). Teen Generation Z is being called 'millennials on steroids,' and that could be terrifying for retailers. Retrieved 13.06.2019, Business Insider UK https://www.businessinsider.in/retail/teen-generation-z-is-being-called-millennialson-steroids-and-that-could-be-terrifying-for-retailers/slidelist/53565468.cms.

Sheeran, P., Abraham, C. and Orbell, S. (1999). Psychosocial correlates of heterosexual condom use: A meta-analysis. Psychological Bulletin, 125, 90-132.

Shih, H.P. (2004). Extended technology acceptance model of Internet utilization behavior. Information \& Management, 41, 719-729.

Shin, D. H. (2010). The Effects of Trust, Security and Privacy in Social Networking: A SecurityBased Approach to Understand the Pattern of Adoption. Interacting with Computers, 22(5), 428-438.

Siamagka, N.T., Christodoulides, C., Michaelidou, N., and Valvi, A. (2015). Determinants of social media adoption by B2B organizations. Industrial Marketing Management, 51, 89-99.

Siti, A., Azizah, O., and Siti, H. (2016). Influence of personal values on generation Z's purchase intention toward natural beauty products. e-Journal of Economics and Management Science, 2, 1-11.

Smith, H. J., Dinev, T., and Xu, H. 2011. Information Privacy Research: An Interdisciplinary Review. MIS Quarterly, 35(4), 989-1016.

Spears, N. and Singh, S. N. (2004). Measuring Attitude toward the Brand and Purchase Intentions. Journal of Current Issues \& Research in Advertising, 26(2), 53-66.

Statista (2019). Mobile phone internet user penetration worldwide from 2014 to 2019. Accessed: 17.05.2017. https://www.statista.com/statistics/284202/mobile-phoneinternet-user-penetration-worldwide/.

Statista (2019). Worldwide mobile app revenues in 2015, 2016 and 2020. Accessed: 19.05.2017. https://www.statista.com/statistics/269025/worldwide-mobile-app-revenue-forecast/

Stocchi, L., Michaelidou, N., and Micevski, M. (2019). Drivers and outcomes of branded mobile app usage intention. Journal of Product \& Brand Management, 28(1), 28-49.

Sultan, F. and Rohm, A.J. (2005). The Coming Era of "Brand in the Hand" Marketing. The growing popularity of cell phones and other hand-held mobile devices has opened up new marketing possibilities. MIT Sloan Management Review, 47(1), 83-95.

Thibaut, J. W. and Kelley, H.H. (1959). The Social Psychology of Groups. New York: John Wiley \& Sons, Inc.

Tojib, D. and Tsarenko, Y. (2012). Post-adoption modeling of advanced mobile service use. Journal of Business Research, 65(7), 922-928.

Tornatzky, L. G. and Klein, K. J. (1982). Innovation Characteristics and Innovation AdoptionImplementation: A Meta-Analysis of Findings. IEEE Transactions on Engineering Management, 29(1), 28-45.

Varnal1, K. and Toker, A.G. (2010). Mobile marketing research: The state of the art. International Journal of Information Management, 30(2), 144-151.

Venkatesh, V., Davis, F. D. and Morris, M. G. (2007). Dead or alive? The development, trajectory and future of technology adoption research. Journal of the Association for Information Systems, 8(4), 267-286.

Viswanathan, V, Hollebeek, L.D., Malthouse, E.C., Maslowska, E., Kim, S.J., and Xie, W. (2017). The dynamics of consumer engagement with mobile technologies. Service Science, 9(1), 36-49.

Watson, R.T., Pitt, L.F., Berthon, P., and Zinkhan, G.M. (2002). U-Commerce: Expanding the Universe of Marketing. Journal of the Academy of Marketing Science, 30(4), 333-347. 
Werner, P. (2004). Reasoned action and planned behaviour. In: S.J. Peterson and T.S. Bredow, eds. Middle range theories: application to nursing research. Lippincott: Williams and Wilkins, 125-147.

Woo, J.H. and Wang, S.C. (2005). What drives mobile commerce? An empirical evaluation of the revised technology acceptance model. Information \& Management, 42, 719-729.

Wu, C.W. (2014). The study of service innovation for digservice on loyalty. Journal of Business Research, 67(5), 819-824.

Wu, J.H. and Wang, S.C. (2005). What drives mobile commerce? An empirical evaluation of the revised technology acceptance model. Information \& Management, 42, 719-729.

Xu, C., Peak, D. and Prybutok, V. (2015). A customer value, satisfaction, and loyalty perspective of mobile application recommendations. Decision Support Systems, 79, 171-183.

Yang, H. (2013). Bon Appétit for Apps: Young American Consumers' Acceptance of Mobile Applications. Journal of Computer Information Systems, 53(3), 85-96. 